$\begin{array}{lllllll}\text { (c) EUSP, } 2016 & \text { e } & \text { ISSN 2310-3817 } & \text { Vol.4 } & \text { SLCSTS No.1 } & \text { p. 54-69 }\end{array}$

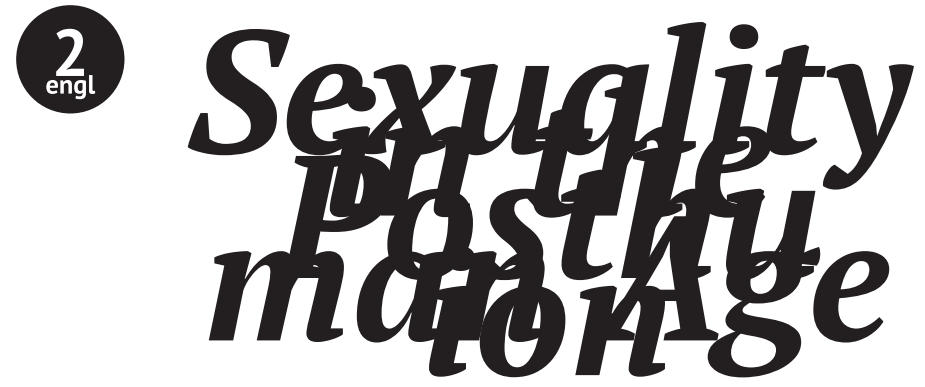

\title{
Slavoj Žižek
}

\section{Sexuality in the Posthuman Age}

\begin{abstract}
The article begins with a critique of the prevalent interpretation of Platonov's novels from the 1920s. These novels supposedly present a critical depiction of the Stalinist utopia and its catastrophic consequences. The article argues against such an interpretation by demonstrating that the aforementioned novels do not present a critique of Stalinism but rather a critique of the gnostic-materialist utopia against which late Stalinism reacted in the early 1930s. The article critically confronts various aspects of this utopia of "biocosmism" as the forerunner of today's technognosis, focusing primarily on its tendency to surpass sexuality as

the last stronghold of the bourgeois counterrevolution. This aspect of the critique of the gnostic-materialist utopia is also at

work in Platonov's essay "The Anti-Sexus," conceived as an advertisement for a masturbatory device. The text discusses this device in the context of the proliferation of gadgets (what Lacan

called les lathouses), the "undead" organs which are not mere supplements of the human organism but rather provide the key to the sexuation of human beings as beings of language.
\end{abstract}

Keywords

Buddhism, enjoyment, Gnosticism, materialism, Platonov, sexuality, Stalinism 
It is the profound distrust of sexual love that is the main feature of Platonov's work throughout the 1920s. His great novels from this periodChevengur and especially The Foundation Pit-are usually interpreted as a critical depiction of Stalinist utopia and its disastrous consequences. Such a view of his work is deeply misleading. Why? The utopia Platonov stages in these two works is not that of Stalinist communism but the gnostic materialist utopia against which mature Stalinism reacted in the early 1930s. What prevails in the aforementioned utopia is rather the so-called biocosmism that effectively acts as a forerunner for today's technological gnosis. This idea was astonishingly widespread, with hundreds of thousands of people, including Trotsky, engaged in the movement (Lenin himself was one of the few who remained skeptical toward it). The idea was that after winning political-economic power, the only way for the working class to effectively win would be to remodel the human being in a genetic, physical, biological way. Put differently, after taking power, the only domain that remained out of its control was that of sexuality as the last trait of the bourgeois counterrevolution. Hence, the plan was to create the New Socialist Man. This was to be done not only by way of Stalinist reeducation but also by way of direct biogenetic interventions. Here we encounter a proper theological moment.

The New Socialist Man would supposedly no longer need sexuality. But in what sense? Not only in the sense that reproduction would be conducted through direct biogenetic means and no longer through sexual copulation, but in a sense that is very close to Malebranche. The idea is that in our ordinary lives we are immediately caught in our bodies, for example, pain is felt in its immediacy. Whereas for the New Communist Man pain should be just a form of information. The functioning of the human being would resemble that of a machine: if it gets too warm, you have some measuring apparatus which tells you "Too hot"; you don't have to feel it, it's just information. So the idea was that the New Man should no longer be directly engaged in feelings: emotions, pain, and so on, but the most physical emotions are treated just as a sign, pure information. You probably know that Malebranche in his occasionalism had already defined the Fall precisely in this way: the Fall happened when Adam, by looking at Eve's naked body, was immediately affected. In Paradise it was as if people were in this dream of utopian communism, they made love but they were not directly engaged in it.

As mentioned, Trotsky was one of the key advocates of biocosmism. Here is a passage from his writings:

What is man? He is by no means a finished or harmonious being. No, he is still a highly awkward creature.

Man, as an animal, has not evolved by plan but spontaneously, and has accumulated many contradictions. The question of how to educate and regulate, of how to improve and complete the physical and spiritual con- 
struction of man, is a colossal problem which can only be understood on the basis of socialism. [...] To produce a new, "improved version" of man-that is the future task of communism. And for that we first have to find out everything about man, his anatomy, his physiology and that part of his physiology which is called his psychology. Man must look at himself and see himself as a raw material, or at best as a semi-manufactured product, and say: "At last, my dear homo sapiens, I will work on you" (Quoted in Figes 2001: 447).

These were not just idiosyncratic theoretical principles, but expressions of a real mass movement in art, architecture, psychology, pedagogy, and organizational sciences, comprising hundreds of thousands of people.

And what is true of Platonov is also true of Zamyatin's dystopian novel We, usually read as a critique of Stalinism. In this case, too, we are rather dealing with a critique of the pre-Stalinist utopia, with the extrapolation of the gnostic-utopian tendency of the revolutionary 1920s against which Stalinism precisely reacted. This, of course, does not imply any rehabilitation of Stalinism; it does, however, counter its superficial understanding. People today rather prefer to forget that avant-garde art was immensely unpopular, and that the Stalinist intervention into culture in the late twenties and early thirties, which culminated in the instauration of socialist realism, was immensely popular. Stalin promised audiences to bring to an end the age of avant-garde dreams, that is, he promised a return to artistic depictions of ordinary people with their love, passions, sentiments, and so on.

Althusser was absolutely right when he insisted that Stalinism was a form of humanism. Stalinism reintroduced humanism even at the level of guilt and the criminal system. What did the Stalinist mock trials mean? They introduced terms like "guilt," "culpability," "repentance," which formally (I know what horror this was in reality) treat victims in some sense as human beings. In contrast to this, the techno-gnostic vision was one of total self-objectification; the counterrevolutionaries weren't considered guilty in any meaningful sense, they were mere malfunctioning machines that should be genetically corrected. The categories of guilt and so on simply didn't exist. For example, one of the first things the Bolsheviks did was to abolish the death sentence. Then, of course, when they captured some prisoners in the civil war they did what they had to do and shot them immediately. And when Western liberals protested in 1919: "Didn't you violate your own proclamations?" They got the answer that they deserved: "But this was not death penalty, this was just a sanitary measure, a purely, completely sanitary operation.” To repeat, in this sense Althusser was right when he insisted that Stalinism was a form of humanism; the true extreme was the gnostic utopian posthumanist 1920s.

My premise is that Platonov was in permanent dialogue with this pre-Stalinist utopian core. With the rise of high Stalinism and its cultural 
counterrevolution, the coordinates of the dialogue changed. Platonov turned toward what cannot but appear a more conformist socialist realist writing-and here lies the problem. Some critics dismiss his late novels, especially his novella The Soul from 1935, as a compromise with Stalinism. Despite the fact that the novella still portrays the utopian group, the nation, the marginal desert community who lost the will to live, the coordinates have totally changed. The hero of the novel is a Stalinist educator, schooled in Moscow, who returns to the desert to introduce the nation, his group, to scientific and cultural progress, and to restore their will to live. However, at the novel's end the hero has to accept that he cannot teach others, and this shift is signalled precisely by the radically changed role of sexuality. I claim that what we effectively find in late Platonov comes very close to the Hollywood formula: the nation disappears to enable the construction of the couple.

This brings me to "The Anti-Sexus" and to three orientations that are independent of each other, sometimes even antagonistic, and, I claim, which provide the background to this essay. First, we have the gnostic equation of sex with the Fall. ${ }^{1}$ Platonov was deeply impressed by the nineteenth-century sect of so-called "Skoptsi," which was widespread in Russia and Eastern Europe, and named after a practice of voluntary castration. To this gnostic approach we have to add the biotechnological prospect of total regulation, even abolition of sex, as well as capitalist consumerism. Modern biotechnology provides a new way to realize the old gnostic dream of getting rid of sex. However, the gadget which does it comes from capitalism and presents itself as the ultimate commodity. Therein resides the subterranean tension of Platonov's essay. The new masturbatory gadget brings together three or even four tendencies: gnostic spiritualism, the reign of modern science, the Soviet total regulation of life, and the capitalist universe of profit-making commodities. Multiple relations are possible between these tendencies. First, there is the tech-gnostic vision that announces the technologically-regulated spiritual withdrawal of posthumans; then there is the capitalist commodification of our innermost experience of orgasm; and finally, we have the tendency towards the posthuman overcoming of sexuality. What makes Platonov's essay "The Anti-Sexus" so rich despite its apparent narrative simplicity is the lack of a general "cognitive mapping": where does the masturbatory machine belong within the space of these coordinates? It is interesting to note that a similar celebration of desexualized vitality also belongs in Stalinism. Although the total mobilization of the first Stalinist five-year plan tended to fight sexuality as the last domain of bourgeois resistance, this did not prevent it from trying to recuperate

See also, Žižek, "From Animal to 'Stamina Training Unit”" In Timofeeva (2012: 6-12). - Eds. 
sexual energy in order to reinvigorate the struggle for socialism. In the early 1930s, a variety of tonics were widely advertised in the Soviet media and sold in pharmacies, with names like "Spermin-pharmakon," "Spermol," and "Sekar fluid-Extractum testiculorum" (see translator's note in Platonov, 2006: 206). The gadget imagined by Platonov neatly fits the ongoing shift in the predominant libidinal economy, in which the relationship to the other is gradually replaced by the captivation of individuals, by what the late Lacan baptized with the neologism les lathousesconsumerist object-gadgets that captivate the libido with the promise of delivering excessive pleasure, but actually only reproduce the lack itself. But before exploring this further, I want to emphasize that in his early, so-called dystopian novels, Platonov is doing something absolutely unique. It is a devastating, if you want, not critique, but rendering open, a display of the nihilism of the Bolshevik passion, most clearly depicted in The Foundation Pit where the great mobilization is staged for building the foundation of some gigantic building to be the house of communism, yet there is nothing-just the hole is dug up.

But at the same time it is absolutely wrong to consider Platonov a dissident in the usual sense. He remains "within," pushing the logic of early communism to its catastrophic, nihilistic consequence, but not providing any withdrawal to the position of the traditional liberal subject. It is in this sense that I claim he is totally different from late humanists, let's call them humanist dissidents, who stand for a proper reaction to Stalinism. Although Stalinism was what it was (extremely brutal, etc.), at the cultural level it rejected modernism and staged a big return to the Russian popular humanist tradition. One cannot dismiss this as mere manipulation. For example, the Russian classics, by the likes of Pushkin and Dostoyevsky, were (re)printed in some ten million copies. Or consider music: it is interesting that the Russian composer selected as the classic in the Stalinist period was neither Mussorgsky nor Rimsky-Korsakov who were, in a manipulative reading, somehow proclaimed more leftist. (Rimsky-Korsakov even lost his university position because he supported the 1905 revolutionaries.) No, it was Tchaikovsky who was proclaimed untouchable with all the consequences this entailed. When Tchaikovsky's letters were reprinted in the Stalinist period, they were censored because, if nothing else, he was totally anti-Semitic, not to mention another interesting detail: his homosexuality. But this, paradoxically, made him more conservative because he discovered that the only homosexual circle in Russia in that period (late mid-nineteenth century) were rich decadent noblemen close to the Tsar. And here Tchaikovsky was extremely harsh in his conservatism. For example, when some revolutionaries staged a terrorist act and the Tsar stopped the execution of the death penalty, changing the sentence to a prison term, Tchaikovsky wrote the Tsar a furious letter saying that they should be shot without mercy. 
In other words, Stalinism for the masses effectively meant the return to this great popular Russian tradition against the avant-garde. And in this sense even authors like Solzhenitsyn remained Stalinist, part of the Stalinist legacy, in the very way they treated Stalinism. George Lukács, whom I admire more and more, has noted that Solzhenitsyn's One Day in the Life of Ivan Denisovich (a short novella that was the first piece of Soviet literature depicting daily life in the gulag) fits all the criteria of Socialist realism, focusing as it did on a positive view of how-even there-you can survive. Lukács pointed out the typical Stalinist motive celebrating work: toward the end of this one day in the life of the prisoner, the work is over and the guard pulls him back, but he remains determined to finish even if he is in danger of the guards punishing him. For Lukács, this scene testifies to the fact that the typically socialist notion of material production as the site of creative practice has survived even in such brutal conditionswhen at the end of the day Ivan Denisovich looks back on his work he sees the wall he has built and realizes that he has enjoyed building it. This is what is so embarrassing for Western critics of communism, where do you put someone like Platonov? You cannot say he was a naïve guy, manipulated or blinded by communism. No, if there was anyone who saw the destructive horror, the abyss that was present there, it was Platonov, and he saw it much better than those Western liberal critics of communism.

In 1935 The New Statesman published a dialogue between Stalin and H. G. Wells, who visited Russia in 1934. After celebrating and thanking Stalin, Wells attempted a small critique and provoked Stalin by saying, isn't it the essence of today's freedom that people are allowed to criticize? That you can see divergent voices and so on. Wells added that it was his impression that Britain doesn't have enough of it, but perhaps neither does the Soviet Union. He thought he would embarrass Stalin who immediately answered that Wells got it wrong, in the Soviet Union this is even more developed than in Britain, adding: "We just call it self-criticism here" (Wells 1935). Another example: when, in the late 1930s, Stalin lowered the age of the death penalty to twelve or thirteen, Western liberals started ironically denouncing this decision as the ultimate example of (false) socialist humanism. Stalin had the perfect answer: this is a sign of the great triumph of our socialist education. Our country is so developed that people of twelve or thirteen years of age already have the maturity of grownup men, and with maturity comes responsibility...

So, again, we have to reject the claims of some leftists who still entertain the utopian dream that if only Lenin were to survive three or four more years, make a pact with Trotsky, they would have gotten rid of Stalin and we would have a wonderfully thriving, democratic Soviet Union-with freedom, with Eisenstein, futurist, avant-garde art, popular with the people and so on and so on. Detailed histories have demonstrated that due to his extreme arrogance, Trotsky deserved to lose. Stalin was nominating people to posts all the time while Trotsky refused to take him seriously, 
thinking: "I'm the great Trotsky, founder of the Red Army, let that guy indulge in his little intrigues, I just need one big speech in the Politburo then I will make it and it will be over for Stalin.” It is incredible the level to which he miscalculated.

Let me return to the uniqueness of Platonov. My first point is as follows: if you really want to understand Stalinism, you have to understand the previous dream, how Stalinism was a reaction to this preceding radical project of the 1920s. The 1920s in the Soviet Union were much more ambiguous than is usually thought, and Platonov offers insight into this era permeated by radical tensions. No wonder Stalin hated him. Stalin's relationship to poets, today celebrated for their greatness, was extremely ambiguous. Stalin almost feared, but also respected them. When in 1933 Osip Mandelshtam wrote his famous "Stalin Epigram," a brutal satirical poem against Stalin, the KGB made plans for his arrest and liquidation as a result. Stalin personally intervened, saying a couple of years of exile would be enough. It was only later, in 1938, when it was too late for Stalinist humanist interventions and the purges had become universal, that Mandelshtam was arrested again. It was the same with Pasternak; he, too, was already on the KGB's liquidation list. Stalin refused, saying Pasternak was a poet, and to leave him alone to "walk on his clouds."

Again, this is the first big lesson learned from Platonov: the preStalinist utopia. The second is the question of where are we today with regard to the process described by Platonov, this technological manipulation of our bodily experience, reality, and so on. I think the ongoing progress in biogenetics is effectively, as it were, changing human nature. François Balmès writes that this progress in biogenetics disrupts

the conditions of human reproduction and radically disconnect[s] it from the encounter of the two sexes, thus opening the possibility of generalized eugenics, of the fabrication of clones, monsters, or hybrids, which shatters the limits of a species. The limits of the biological real are effectively displaced, and the most secured constraints of what is to be symbolized, life, death, filiation, bodily identity, the difference of the sexes, are rendered friable. Cloning allows us, in principle, to get rid of a partner, and thereby of the other sex, or of the alterity as such: one perpetuates oneself without alteration. There is a historical mutation in this which is at least as radical as the death of the human species made possible by nuclear fission (Balmès 2011:16).

Indeed, the neurodiscourse in which a person is equated to his or her brain has penetrated all aspects of our lives, from law to politics to literature to medicine to physics. ${ }^{2}$ As part of this neurorevolution, huge military

2 I rely here on Hady (2012). 
funds are invested in neuroscientific research; the most conspicuous case is that of the (in)famous American DARPA (Defense Advanced Research Projects Agency), which comprises three strands: narrative analysis, augmented cognition (along the lines of the Iron Man project, etc., to create soldiers with enhanced cognitive capacities), and autonomous robots (aiming to convert a large fraction of the military into a robotic one, which is easier to control, will decrease the economic burden of having military personnel, and will reduce losses in terms of soldiers' lives). Autonomous robot-soldiers can also be used to ruthlessly stop protests and crack down on citizens in cases of civil disobedience. The basic idea of DARPA is to protect citizens of the United States from (foreign) bad guys by figuring out how vulnerable some people are to terrorist "narratives" (oral stories, speeches, propaganda, books, etc.), and then supplanting such narratives with better ones. To put it simply, DARPA endeavors to shape minds with stories. But how? Here is the catch: DARPA would like to revolutionize the study of narrative influence by extending it into the neurobiological domain. The standard narrative analysis thus takes an ominous turn: the goal is not to convince the potential terrorist through apt rhetoric or line of argument (or even plain brainwashing), but to directly intervene in his brain to make him change his mind. Ideological struggle is no longer conducted through argument or propaganda, but by means of neurobiology, that is, by way of regulating neuronal processes in our brain. Again, the catch is: who will decide what narratives are dangerous and, as such, deserve neurological correction? Incredible experiments are being done here. For example, there could be a pill that changes your perception of time, so that you experience one minute as one day and so on... And then come ideas of how to profit from this. Let's say I commit a rape or a similar crime, and am sentenced to five or ten years. But let's say I am (which I am not) a big scientist of profit to humanity so it would be sad to lose me for this time. So the idea is that I am imprisoned for five or ten years but I take that pill so that in reality, society will only lose me for one day while I experience it as ten years. OK, my immediate association would be why just punishment, why not sex? (You are only doing it one minute but...) So, again, what I want to emphasize here is that we are not talking about some dreams and so on... DARPA is already doing this.

We should not reduce this posthuman stance to the modern belief in the possibility of total domination over nature, we should not reduce it to the supposed Cartesian arrogance (even human nature will become totally available, we will create people whose emotions will be controlled, at the same time their abilities-intelligence, etc.-will be enhanced). French theorist of catastrophes Jean-Pierre Dupuy detected this tendency, namely a weird reversal of traditional Cartesian anthropocentric arrogance, which grounds human technology-a reversal clearly discernible in today's robotics, genetics, nanotechnology, artificial life, and Artificial Intelligence research. 
How are we to explain that science became such a "risky" activity that, according to some top scientists, it poses today the principal threat to the survival of humanity? Some philosophers reply to this question by saying that Descartes' dream - "to become master and possessor of nature"-has turned out bad, and that we should urgently return to the "mastery of mastery." They understand nothing. They don't see that the technology profiling itself at our horizon through the "convergence" of all disciplines aims precisely at non-mastery. The engineer of tomorrow will not be a sorcerer's apprentice because of his negligence or ignorance, but by choice. He will "give" himself complex structures or organizations and will try to learn what they are capable of by exploring their functional properties [-an ascending, bottom-up, approach. He will be an explorer and experimenter at least as much as an executor]. The measure of his success will be more the extent to which his own creations will surprise him than the conformity of his realization to a list of preestablished tasks (Dupuy 2004, quoted in Besnier 2010: 195).

Here Dupuy is right: this traditional Cartesian idea of modern science, an idea of total domination, is a much more obscure desire to create a monster that will surpass us. What we want is artificial intelligence that will start to reproduce itself-we want to be surprised. So instead of seeing in it some danger, we should, instead of just dismissing it, see in it an extremely interesting new constellation where we simply don't know where we're going. On the one hand humanity is, in some sense, at its end. By this I mean, for example, the very basic fact of our being human, that is, you distinguish between inner and outer life (my thoughts are within me, reality is out there): without this minimal distance we are not human. This is already being transgressed. We are all familiar with these old stories, you even hear them in the media, how even Stephen Hawking no longer needs his proverbial little finger. Today you can already, still very primitively but nonetheless, directly wire your brain to a machine. The problem is that, on the one hand, you become God-like: you think about something, it happens. I've seen wheelchairs for disabled people, you just think "on" and the machine moves, you think "left," the machine moves left. This corresponds to what the German idealists called "intellectual intuition," your ideal intuition immediately coincides with the real, it has creative power. The problem is-to be vulgar-that what goes out also goes in. If you can influence the outer world in this way, it goes also the other way, meaning that our "inner life" can also be controlled. So I think this is one development connected with the possibilities of biogenetics which are all pretty primitive. But nonetheless something is emerging here, we don't know what it will mean but it opens up some very interesting questions. Freud, in his Civilization and its Discontents, already anticipated this development when he spoke about the so-called "prosthetic god," the artificial enhancement of our capacities, and saw very well how 
this causes even more anxiety and discontent. This is what those ridiculous, mostly boring, films about superheroes like Batman, Superman, and Spiderman indicate. ${ }^{3}$

Lacan clearly saw this tendency, when in his Ethics seminar he evoked the "point of the apocalypse" (Lacan 1992: 207), the impossible saturation of the Symbolic by the Real of jouissance, the full immersion into massive jouissance. When, in a Heideggerian way, he asks: "Have we crossed the line...in the world in which we live?" (1992: 231), he is alluding to the fact that "the possibility of the death of the Symbolic has become a tangible reality" (Chiesa 2007: 177). Lacan mentions the threat of atomic holocaust; today, however, we are in a position to offer other versions of this death of the Symbolic. At that time, Lacan already saw that the problem is not so much that we will be dwarfed by machines but that we are already entering a new stage where these technological supplements will no longer be "out there" as big machines but will just be tiny pieces of technology implanted into us. So we will not even be able to experience them as such, as an external machine...It will not be a universalized, let's call it, dialysis (there is something traumatically humiliating about seeing a machine outside yourself, and your very life, reproduction, depending on it). No, these implants will become invisible, doing their job at a level well below the threshold of our perception. What makes nanotechnology so thrilling is the prospect of constructing objects and processes in such a small dimension that all correlation with our ordinary life-world is effectively lost, as if we are dealing with an alternate reality: there are no shared scales between nano-reality and our ordinary reality, and yet we can influence our reality and manipulate it through nano-processes.

The changed status of science implied from a profusion of objects entirely forged by science is focused on by the late Lacan, who emphasizes:

What science is such as we have it now, if I can put it like this, on our hands-I mean, present in our world in a manner that goes well beyond anything that an effect of knowledge may lead us to speculate about.

In effect, it is, all the same, necessary not to forget that it is characteristic of our science not to have introduced a better and more extensive knowledge of the world but to have brought into existence, in the world, things that did not in any way exist at the level of our perception (Lacan 2007: 158).

So science and technology today no longer just aim at understanding and reproducing natural processes, but at generating new forms of life that will surprise us; the goal is no longer only to dominate existing na-

3 I cannot but mention the ironic fact that the title of the last Superman film, The Man of Steel, is a literal English translation of Stalin. 
ture, but to generate something new-greater and stronger than ordinary nature, including ourselves (note the obsession with artificial intelligence, aimed at producing a brain stronger than the human). The dream that sustains the scientific-technological endeavor is to trigger a process with no return, a process that would reproduce itself exponentially and continue on its own. Can one even imagine the unforeseen result of nano-technological experiments, new life forms reproducing themselves out of control in a cancer-like way? Here is a standard description of this fear:

Within fifty to a hundred years, a new class of organisms is likely to emerge. These organisms will be artificial in the sense that they will originally be designed by humans. However, they will reproduce, and will "evolve" into something other than their original form; they will be "alive" under any reasonable definition of the word. [...] the pace of evolutionary change will be extremely rapid. [...] The impact on humanity and the biosphere could be enormous, larger than the industrial revolution, nuclear weapons, or environmental pollution (Farmer and Belin 1992: 815).

This fear also has its clear libidinal dimension: it is the fear of the asexual reproduction of life, the fear of an "undead" life that is indestructible, constantly expanding, reproducing itself through self-division. In short, the fear of the mythic creature that Lacan calls lamella, presenting the libido as an inhuman organ without a body, the mythic, pre-subjective, undead life substance. Because what makes gadgets so uncanny is the fact that, far from simply supplementing human organs, they introduce a logic that fundamentally differs from, and so unsettles, the "normal" libidinal economy of sexed human beings qua beings of language. Techno-gadgets are potentially "undead," they function as parasitic "organs without bodies" which impose their repetitive rhythms onto the beings they are supposed to serve and supplement. And, again, this is the vision Lacan sees in our world as increasingly populated by what he calls lathouses as undead objects. We can see why, apropos lathouses, we have to include capitalism. We are dealing here with a whole chain of surpluses: scientific technology with its surplus-knowledge (a knowledge beyond mere connaissance of already existing reality, a knowledge which is embodied in new objects); capitalist surplus-value (the commodification of this surplus-knowledge in the proliferation of gadgets); and, last but not least, surplus-enjoyment (gadgets as forms of the objet $a$ ), which accounts for the libidinal economy the hold of lathouses has over us.

I nonetheless see in this one perspective of emancipating human pleasure. The story goes like this. We have different gadgets. For women there is the plastic penis, but for men there is something called a "Stamina Training Unit," a discretely designed plastic vagina that looks like a 
torch and comes with different plastic covers (you can put on a plastic vagina opening, anal opening or mouth), and in different models with more or less hair. The user can regulate the density and frequency of the vibrations. Based on this let me imagine a date that, I think, would fully satisfy. Let's say I flirt with a woman and we decide to "do it." We meet somewhere, at her place, and I come with my Stamina Training Unit, she comes with her dildo, we connect both machines, put the plastic penis into the machine and both machines run; our superego duty to enjoy is out there, while we can relax, have a nice conversation, see a movie, and so on. We are free from the superego, and this freedom from obscene fantasies enables us to do more civilized things...

I recently remembered one of my infantile fantasies. The fantasies of "where babies come from" are crazy but it's wrong to think that once you are mature it is "real sex" and you don't need fantasies. No, the paradox of human beings is that you need, in a more developed form, these fantasies to the very end. As a child I knew that storks deliver babies, but then I had a problem; I finally learned about sex, but still, in my naivety, couldn't believe it. This was almost a Catholic reaction: "how could something as noble and innocent as a child come from naked sweating bodies mingling there?" And I found a solution: yes, you need sex for making babies, but every reasonable being nonetheless knows storks bring them. So while you are making love a stork is observing you, and if you perform well, you get a baby as a kind of reward. And our sexuality functions like that. So if you remember-the machines are buzzing and we no longer have this duty; our duty to have sex is done. And then I talk with the woman and by chance our hands meet and maybe, just maybe, we end up in bed. We already did it for the big Other, so this would be pure surplus.

If we accept that we are approaching this posthuman era, we encounter the big philosophical problem of (im)possibility symbolizing this result. Science is telling us we are not human beings but rather automata, manipulated biologically. But can we change our experience to something that would be appropriate with this image? And here things get interesting. Some cognitivists claim that we can only know this about our biological mechanism objectively, but cannot really accept it, meaning that we necessarily experience ourselves as free agents. Then you have the "transcendental," Habermasian version of this argument, claiming that the sciences are, of course, true, but they are social practices enacted in a certain intersubjective community. This is an irreducible aspect because you cannot say: "But we can account for how the intersubjective community came to be with a neurological explanation," because in order to give a neurological explanation the scientific community as the transcendental a priori has to be here. Then we have the third position, which I must say I quite appreciate. The third position is the position of radical cognitivists like Patricia and Paul Churchland, who claim that we can change our subjective attitudes so that we incorporate the results of cognitivism 
in our daily life. But to me this doesn't work because it relies on the assumption that the old, free, independent subject is still here.

Thomas Metzinger, at the same time both a German cognitivist and Buddhist, brings this logic to a totally different and very radical conclusion: he claims the only thing (I wouldn't use the word philosophy) which enables us to integrate-to subjectively experience this fact that there is no self, that we are just neurological automata or "thoughts without thinker"-is Buddhist enlightenment. When you reach Buddhist enlightenment, you really think without being a subject; there enunciation and enunciated coincide. Despite some problems with such a conclusion, I nevertheless find it interesting how in Buddhism again and again the same deadlock repeats itself, a deadlock which points, I claim, at the persisting form of subjectivity. For instance, think of how Buddhism has confronted the problem of war. When they build a new house Tibetan Buddhists are allegedly very attentive not to kill a single worm. What I want to say is that from the very beginning, when the Buddha was already old and some kings converted to Buddhism, they insisted that the State required an army. And Buddhism found three ways, each more ominous than the preceding one, to nonetheless justify killing during war.

The first is the standard way, which you also find in the West: killing is allowed when you do it to prevent an even greater evil. The problem of course is where this logic stops. When Japan invaded China in the early 1930s their justification was strictly this-that the Chinese are a spoiled people, and we invaded them to bring peace. Then there is the second version: when you acquire distance, you are out of the Circle of Life, so your acts are no longer inscribed into karma and you can do whatever you want. You find this line from the very beginning, that killing is evil but only insofar as you as a person are engaged in it; if you are doing it from the position of the one who is already liberated, it becomes acceptable. The definition of liberation in Buddhism is something very radical; it implies that you exempt yourself from this Circle of Life where your acts leave no traces. This is a more sophisticated version of the first argument which goes like this: Yes, every killing leaves traces (if I kill someone, I will be born as a lowly worm instead of a lion); but, they say, if the one whom you killed is really evil and would in the following days have killed a hundred people-but hadn't yet killed them-I prevent him from acquiring bad karma from future killings. In this way I have saved him and thus am performing the ultimate heroic act of acquiring a little bit of bad karma to allow the other, for instance, to be reborn as another philosopher. Here comes the Stalinist trick: because I performed this heroic act of assuming bad karma to prevent the other from acquiring it, this is the ultimate ethical act and that is why my bad karma turns into good karma, into profit.

I claim that the greatest catastrophe of Buddhism begins with the notion of bodhisattva, meaning the one who already reached enlightenment but out of sympathy with all the suffering in the world returns to this real- 
ity. He says: "No, I will remain within this circle of ordinary phenomenal reality of suffering until all people, or even all sentient beings, will also be delivered of that pain." This idea causes terrible conflict among Buddhists because Buddhism oscillates between two extreme forms of enlightenment: on one hand, you have this, let's call it a radical realist idea, that enlightenment means a universal event where all suffering will disappear. On the other hand, you have a much more convincing and authentic minimalist version which claims that the Buddha is not the one who lives in the clouds and then returns to help us; to be really enlightened doesn't mean you move somewhere else, you remain here, fully and directly as a human being, but already enlightened. What changes is only your attitude towards reality. Buddhism constantly oscillates between these two extremes; this is why among Buddhists you can find extreme pacifists as well as radical advocates of killing. The most beautiful version of this I owe to Ang Lee who told me about a Chinese Buddhist monk who says he will refuse to become bodhisattva not only to the level of when all will be redeemed, but he says that in this we should also include all those in hell who are suffering eternal damnation. Ang Lee, being a nationalist, added one exception: Mao (because of the Cultural Revolution) should suffer forever. Aside from extreme pacifists we also encounter extreme militarists like Japanese Buddhists who position themselves outside of the cycle of karma, which enables them to do as they please.

Allow me a brief interruption. The problem here is also suffering, hell, which is such a suspicious entity. In Thomas Aquinas you find a beautiful problem: let's say that if we are good people we will be in heaven; we will be allowed to observe the suffering of those in hell. Aquinas even claims that seeing the suffering in hell will strengthen our pleasure of being in paradise. Now, of course he immediately confronts the problem: how can this be part of heaven that you find excessive pleasure in seeing other people suffering eternal torments? The job that Aquinas does here is typical scholastic sophistry; he distinguishes two levels of pleasure: the direct pleasure in the pain of others, and the pleasure in divine justice. So what is the true solution here? Some time ago I debated (and mocked) this problem with Rowan Williams, the ex-Archbishop of Canterbury. He agreed with my solution, that we should imagine it the other way around. In heaven you drink nectar and partake in all sorts of pleasures but eventually grow tired of them, then some angel, who takes care of the administration in heaven, comes to give you a boost so that you don't complain, reminding you of the suffering of others. It's obvious that in heaven you immediately get depressed and bored, while hell is quite a nice place and the devil is basically a benevolent god (as we know from Lubitsch's Heaven Can Wait). As we all know, in hell we have good times, we have sex, we drink, and so on. But from time to time the administrator of hell comes and says: "Look guys, we are having a nice time but I just learned that for the next five minutes we will be observed by heaven. 
So please, to save our life here, pretend that you suffer a little bit so that we impress them and then we can go on with violence, etc."

The Buddhist notion of enlightenment, however, confronts us with yet another problem. Today, it is more or less proven that a state which at least looks like nirvana can be achieved through pills. And here some Buddhists have a great problem, because biochemistry is already producing what are ironically called "enlightenment pills." Why go through that tiring process of spiritual elevation and so on, if you can simply take a pill and you are "there"? The issue is painful because the measurements of our brain activity demonstrate that our inner experience of enlightenment is exactly the same. Along the lines of scholasticism, the desperate attempt of some Buddhists is to distinguish deserved from undeserved happiness. Chemical happiness doesn't count because it is undeserved. But I think this is totally against the whole logic of Buddhism, it introduces a certain ethics which is at odds with Buddhism as such. All of this nevertheless shows that Buddhist ethics don't work, not in the sense that Buddhist enlightenment is not a radical authentic experience. The problem is rather that it gets caught ethically in a dilemma that can be formulated in the following, vulgar way: "Why can't I go on raping women, torturing people and so on, and still retain my enlightenment?" I think this is an embarrassing question to which Buddhism can't provide a proper answer. The solution, however, can be found in the Western Judeo-Christian, even Islamic tradition. (I say Islamic because there is a beautiful line which is often quoted from Islam which says that God only prescribes rituals, being totally indifferent to what you "really" believe.) Here we have to opt for the total externalization of ethics, and this is the lesson of our Judeo-Christian tradition. "Inner life" doesn't matter; all criminals have an "inner life," "their own story to tell," but the point is that the "authentic" inner life is but a mask, a fantasy that we fabricate to escape the consequences of our acts.

\section{Bibliography}

Balmès, François (2011). Structure, logique, aliénation. Toulouse: Érès.

Besnier, Jean-Michel (2010). Demain les posthumains: Le futur a-t-il encore besoin de nous? Paris: Fayard.

Chiesa, Lorenzo (2007). Subjectivity and Otherness: A Philosophical Reading of Lacan. Cambridge, MA: MIT Press.

Dupuy, Jean-Pierre (2004). "Le problème théologico-scientifique et la responsabilité de la science.” Le Débat 129: 175-92.

Farmer, J. Doyne, and Belin, Aletta d'A. (1992). “Artificial Life: The Coming Evolution.” In Artificial Life, ed. C. G. Langton et al., 815-40. Reading, MA: Addison-Wesley.

Figes, Orlando (2001). Natasha's Dance: A Cultural History of Russia. London: Allen Lane. 
Hady, Ahmed El (2012). "Neurotechnology, Social Control and Revolution.” Big Think. http://bigthink.com/hybrid-reality/neurotechnology-social-control-and-revolution.

Lacan, Jacques (1992). The Ethics of Psychoanalysis. London \& New York: Routledge.

Lacan, Jacques (2007). The Other Side of Psychoanalysis. London \& New York: W. W. Norton.

Platonov, Andrey (2009). The Foundation Pit. New York: NYRB.

Platonov, Andrey (2013). “The Anti-Sexus.” Trans. Anne. O. Fisher. Cabinet 51: 48-53.

Wells, H. G. (2014). "H. G. Wells: 'It seems to me that I am more to the Left than you, Mr Stalin'”. New Statesman [27 October 1934]. http://www.newstatesman.com/ politics/2014/04/h-g-wells-it-seems-me-i-am-more-left-you-mr-stalin.

Žižek, Slavoj (2012). “From Animal to 'Stamina Training Unit'.” In An Essay on Negativity, Immanence, and Freedom, ed. Oxana Timofeeva, 6-11. Maastricht: Jan van Eyck. 